\title{
Studi in vivo ekstrak etanolik ciplukan (Physalis angulata) dalam meningkatkan apoptosis sel kanker lidah
}

\author{
Ulfah Hermin Safitri*, Eriska Firma Nawangsih ${ }^{*}$, Naida Dwi Noviyanti ${ }^{*}$, Fitria Nur'aini*, Diyah apliani, Tetiana Haniastuti ${ }^{\star \star}$ \\ ${ }^{*}$ Fakultas Kedokteran Gigi, Universitas Gadjah Mada, Yogyakarta, Indonesia \\ ${ }^{* *}$ Departemen Biologi Mulut, Fakultas Kedokteran Gigi, Universitas Gadjah Mada, Yogyakarta, Indonesia \\ *JI Denta No 1, Sekip Utara, Yogyakarta, Indonesia; e-mail: herminoosafitri@gmail.com
}

Submisi: 11 Juni 2015; Penerimaan: 12 Juni 2016

\begin{abstract}
ABSTRAK
Kanker lidah merupakan jenis kanker di dalam rongga mulut yang sering terjadi dan memiliki prevalensi yang tinggi. Ciplukan (Physalis angulata L.) memiliki aktivitas sitotoksik pada sel kanker, yaitu mampu menghambat proliferasi sel kanker dan menginduksi cell cycle arrest. Penelitian ini bertujuan mengkaji potensi ekstrak etanolik ciplukan (EEC) sebagai antikanker lidah dan mengetahui pengaruh EEC dalam meningkatkan apoptosis sel kanker lidah yang diinjeksi DMBA. Lima belas ekor tikus Sprague dawley betina usia 2-3 bulan dibagi menjadi tiga kelompok yaitu: (1) kelompok kontrol DMBA; (2) kelompok DMBA+EEC dosis $750 \mathrm{mg} / \mathrm{kg} \mathrm{BB;} \mathrm{(3)} \mathrm{kelompok} \mathrm{DMBA+EEC} \mathrm{dosis} 1500 \mathrm{mg} / \mathrm{kg} \mathrm{BB}$. Kanker lidah diinduksi dengan injeksi $0,1 \mathrm{ml} / 100$ gram BB tikus larutan DMBA $\%$ pada bagian lateral lidah hewan uji satu kali, lalu dibiarkan selama 5 minggu. Pada awal minggu ke-6 EEC 750 dan $1500 \mathrm{mg} / \mathrm{kg}$ BB diberikan secara sondasi kepada hewan uji selama 7 hari. Pada awal minggu ketujuh tikus dikorbankan. Selanjutnya, dilakukan pengamatan untuk memeriksa apoptosis sel dengan pewarnaan TdT-mediated X-dUTP Nick End Labeling (TUNEL). Hasil penelitian menunjukkan indeks apoptosis kelompok kontrol adalah 3,94\%, kelompok perlakuan EEC $750 \mathrm{mg} / \mathrm{kg}$ BB adalah 15,34\%, dan kelompok perlakuan EEC $1500 \mathrm{mg} / \mathrm{kg}$ BB sebesar 25,5\%. Hasil uji One Way ANOVA $(p<0,05)$ menunjukkan bahwa EEC mampu meningkatkan apoptosis sel kanker lidah tikus yang diinduksi DMBA. Kesimpulan penelitian ini adalah EEC dapat menghambat pertumbuhan sel kanker lidah dengan cara meningkatkan apoptosis sel kanker lidah tikus.
\end{abstract}

Kata kunci: apoptosis7, 12-dimetilbenz[a]antrasen (DMBA), kanker lidah, Physalis angulata $L$

\begin{abstract}
In vivo study of ethanolic ciplukan extract (Physalis angulata) to enhance the apoptosis of tongue cancer cell. Tongue cancer is kind of oral cancer with high prevalence. Ciplukan (Physalis angulata L.) has cytotoxic activity to inhibit cancer cells proliferation and induct cell cycle arrest. This study aims to assess the potential of ethanolic ciplukan extract (ECE) as anti tongue cancer and determine the effect of ECE in increasing tongue cancer cells apoptotic injected by DMBA. Fifteen female Sprague dawley rats of approximately 80-60 gram and aged 2-3 months were divided into three groups: (1) control group; (2) DMBA+ $750 \mathrm{mg} / \mathrm{kg} \mathrm{BW} \mathrm{ECE;} \mathrm{(3)} \mathrm{DMBA+1500} \mathrm{mg/kg} \mathrm{BW} \mathrm{ECE.} \mathrm{Tongue} \mathrm{cancer}$ was inducted by injecting $2 \%$ DMBA $0,1 \mathrm{ml} / 100$ grams $B W$ on the lateral tongue and then it was observed for 5 weeks. After that, the 750 and $1500 \mathrm{mg} / \mathrm{kg}$ BW ECE were given orally everyday for seven days. By the end of the sixth week, all the rats were sacrified and then the tongue tissue was stained using TdT-mediated X-dUTP Nick End Labeling (TUNEL) assay to see the apoptotic cells. The results showed that apoptotic index for the control group was 3,94\%, treatment with $750 \mathrm{mg} / \mathrm{Kg}$ BW extract had $15,34 \%$ result meanwhile treatment with $1500 \mathrm{mg} / \mathrm{Kg} B W$ resulted in $25,5 \%$. The result of one way ANOVA $(p<0,05)$ test showed that ECE increased cancer cells apoptotic treated by DMBA. Thus, it is possible to conclude that ECE is effective in inhibiting the growth of tongue cancer cell by increasing apoptotic tongue cancer cells.
\end{abstract}

Keywords: 7,12-dimetilbenz[a]antrasen (DMBA), tongue cancer, Physalis angulata L., apoptotic

\section{PENDAHULUAN}

Kanker lidah merupakan salah satu jenis kanker di dalam rongga mulut yang memiliki prevalensi tinggi atau sering terjadi dibandingkan kanker di rongga mulut lainnya. Kanker lidah adalah kanker primer kedua terbanyak setelah kanker bibir. ${ }^{1}$ Dari 441 kanker lidah, 25\% terjadi pada wanita dan $75 \%$ terjadi pada pria. ${ }^{2}$ Berdasarkan hasil analisis Riskesdas 2007,3 Jawa Tengah memiliki prevalensi kanker rongga mulut dan tenggorokan terbanyak dari 203 kasus yang terjadi di Indonesia, yaitu sebesar $0,2 \% .{ }^{4}$ Faktor yang mempengaruhi terjadinya kanker lidah yaitu faktor lokal meliputi kebersihan rongga mulut yang buruk, iritasi kronis dari restorasi, dan karies gigi, sedangkan faktor luar antara lain kebiasaan merokok, minum alkohol, 
menyirih, virus, serta faktor host meliputi usia jenis kelamin, nutrisi, sistem imun, dan genetik. ${ }^{4}$ Oleh sebab itu harus diusahakan pemilihan pengobatan kanker lidah yang baik dan efektif.

Peningkatan apoptosis merupakan salah satu target dalam pengobatan kanker lidah. Apoptosis merupakan suatu proses seluler yang terjadi baik dalam keadaan fisiologis dan patologis untuk mengatur jumlah sel. ${ }^{5}$ Pada sel normal, jumlah sel diatur oleh keseimbangan pembelahan sel (proliferasi) dan kematian sel (apoptosis). Tidak terkontrolnya pembelahan sel yang terjadi akan menyebabkan kanker. ${ }^{6,7}$

7,12-dimetilbenz[a]antrasen (DMBA) merupakan golongan Polycyclic Aromatic Hydrocarbon (PAH) yang diketahui bersifat sebagai karsinogen pada manusia. ${ }^{8}$ Oksidasi metabolik DMBA akan menghasilkan metabolik epoksida yang sangat reaktif sehingga mampu memicu karsinogenesis. ${ }^{9}$ Metabolit reaktif DMBA akan membentuk adduct pada DNA sehingga terjadi mutasi DNA yang menyebabkan perubahan sifat sel-sel normal menjadi sel kanker yang tak terkontrol. ${ }^{9}$

Beberapa peneliti melaporkan bahwa senyawa-senyawa dalam tanaman memiliki potensi sebagai agen kemopreventif sehingga dapat mengurangi resiko kanker. ${ }^{10}$ Salah satu tanaman yang menarik untuk ditelusuri aktivitasnya sebagai agen kemopreventif adalah ciplukan (Physalis angulata L.). Senyawa aktif yang diduga sebagai antikanker pada herba ciplukan adalah fisalin. Ekstrak etanolik herba ciplukan (EEC) secara in vitro memiliki aktivitas sitotoksik dan mampu menginduksi terjadinya apoptosis pada sel kanker leher rahim HeLa dan sel kanker payudara MCF7. ${ }^{11,12}$ Fisalin $B$ dan fisalin D memberikan aktivitas sitotoksik pada beberapa sel kanker. ${ }^{13}$

Untuk mengoptimalkan potensi ciplukan sebagai agen kemoprevensi terutama pada kanker lidah, maka tujuan penelitian ini adalah untuk mengetahui pengaruh EEC terhadap peningkatan apoptosis sel kanker lidah tikus Sprague Dawley yang diinjeksi DMBA $2 \%$. Apabila terbukti bahwa EEC dapat menghambat karsinogenesis pada sel kanker lidah, maka herba ini dapat dikembangkan sebagai salah satu alternatif agen kemoprevensi.

\section{METODE PENELITIAN}

Disain penelitian adalah penelitian eksperimental laboratorium dengan mengamati aktivitas apoptosis sel kanker lidah tikus yang diinjeksi DMBA dengan perlakuan EEC 750 dan 1500 mg/ $\mathrm{kg}$ BB. Ethical clearance diperoleh dari Komisi Etik Penelitian FKG UGM No. 706/KKEP/FKG-UGM/ EC/2014.

Penelitian berjalan selama empat bulan pada bulan Januari sampai April 2015 di Laboratoium Taksonomi Tanaman Bawah Fakultas Biologi UGM, Laboratorium Farmasi Fakultas Farmasi UGM, Laboratorium Pengujian dan Penelitian Terpadu UGM, Laboratorium Patologi Anatomi Fakultas Kedokteran UGM, Laboratorium Parasitologi Fakultas Kedokteran UGM.

Bahan uji yang digunakan dalam penelitian ini adalah herba ciplukan terdiri dari semua bagian tanaman kecuali akar (Physalis angulata L.) yang diambil dari daerah Ngaglik, Sleman, Yogyakarta pada bulan Februari 2015 dan dideterminasi di laboratorium Taksonomi Tumbuhan Bawah, Fakultas Biologi UGM. Pembuatan EEC dilakukan dengan teknik maserasi di Laboratorium Farmasi Fakultas Farmasi UGM. Herba ciplukan yang sudah dibuat serbuk akan diekstraksi dalam larutan 1,5 liter etanol 96\%, kemudian ekstrak yang sudah jadi akan dipekatkan dengan bantuan rotary evaporator. Ekstrak ini kemudian akan diencerkan dengan akuades untuk memperoleh dosis $750 \mathrm{mg} /$ $\mathrm{kg} \mathrm{BB}$ dan $1500 \mathrm{mg} / \mathrm{kg} \mathrm{BB}$.

Hewan uji yang digunakan dalam penelitian ini adalah tikus betina galur Sprague Dawley berumur 2-3 bulan dengan berat 80-160 gram sebanyak 15 ekor yang diperoleh dari Laboratorium Penelitian dan Pengujian Terpadu UGM. Sebanyak 5 ekor pada tiap kelompok ( 3 kelompok) yang ditempatkan dalam kandang dengan suhu sekitar $28-32{ }^{\circ} \mathrm{C}$, kelembaban nisbi $98 \%$ dan diberikan minum ad libitum dan makaan berupa pellet. Tikus akan diadaptasi selama 3 hari.

Bahan kimia yang digunakan dalam penelitian ini adalah 7,12 dimetilbenz (a) antrasen atau DMBA (Sigma) sebagai bahan untuk induksi kanker, aseton sebagai pelarut DMBA, etanol sebagai 
pelarut herba ciplukan, akuades sebagai pelarut ekstrak, formaldehid (Sigma) sebagai larutan fiksasi organ, TUNEL sebagai pewarnaan untuk melihat apoptosis.

\section{Prosedur Penelitian}

\section{Uji in vivo}

Dalam penelitian ini, perlakuan terhadap hewan uji dilakukan untuk melihat peningkatan apoptosis karena pemberian DMBA dan ekstrak etanolik herba ciplukan pada sel kanker lidah. Tikus dibagi dalam tiga kelompok masing-masing kelompok terdiri dari lima ekor tikus. Kelompok (1) kelompok DMBA+EEC dosis $750 \mathrm{mg} / \mathrm{kg} \mathrm{BB}$; (2) kelompok kontrol DMBA + EEC dosis 1500 mg/ kgBB (3) kelompok kontrol DMBA. Kanker lidah diinduksi dengan injeksi secara intrasubmukosa $0,1 \mathrm{ml}$ per 100 gram BB tikus larutan DMBA 2\% sebanyak satu kali pada bagian lateral lidah hewan uji, lalu didiamkan selama 5 minggu. Perlakuan EEC 750 dan $1500 \mathrm{mg} / \mathrm{kg}$ BB diberikan secara sondasi kepada hewan uji pada awal minggu keenam selama 7 hari. Pada akhir perlakuan, yaitu pada minggu ketujuh tikus dikorbankan dan diambil jaringan lidahnya.

\section{Pengamatan apoptosis sel dengan pewarnaan TUNEL}

Deparafinasi dilakukan sebelum potongan preparat jaringan lidah yang terblok parafin dicat menggunakan TUNEL Assay, bertujuan untuk mengilangkan parafin. Potongan preparat jaringan lidah dimasukkan ke dalam larutan xylol selama 3 menit. Setelah itu dimasukkan ke dalam alkohol dengan konsentrasi bertingkat 95\%, 90\%, 80\%, $70 \%$ (masing-masing konsentrasi direndam selama 5 menit). Selanjutnya preparat dicuci menggunakan air mengalir sampai sisa alkohol hilang, lalu dicuci menggunakan PBS selama 15 menit, kemudian dicuci menggunakan akuades selama 2 menit kemudian diinkubasi semalam di inkubator pada suhu $45^{\circ} \mathrm{C}$. Setelah itu dilakukan rehidrasi preparat jaringan lidah dengan akuades steril, kemudian ditambah dengan $50 \mu \mathrm{l}$ TUNEL label mix (enzyme solutiondengan $\mu \mathrm{l}$ labeling solution) dengan TdT. Preparat ditutup dengan siliconized cover slip. Preparat diinkubasi pada suhu $37{ }^{\circ} \mathrm{C}$ selama
30 menit di dalam moist chamber, hal ini dapat dilakukan karena merupakan reaksi enzimatis. Preparat dicuci dengan Phosphate Buffered Saline (PBS) sebanyak 3 kali dan diinkubasi dengan RNase solution pada suhu $37^{\circ} \mathrm{C}$ selama 30 menit, lalu preparat dicuci lagi dengan PBS sebanyak 3 kali. Preparat selanjutnya diinkubasi dengan larutan propidium iodide pada suhu ruang selama 10 menit. Preparat dicuci dengan PBS sebanyak 3 kali dan ditutup dengan cover slide diameter $18 \mathrm{~mm}$.

Pengamatan apoptosis dilakukan dengan menggunakan mikroskop fluorosen dengan perbesaran 400x. Sel apoptosis yang dihitung adalah sel yang berwarna hijau dan sel tunggal pada 1000 sel dalam 1 lapang pandang. Perhitungan yang dilakukan pada 10 lapang pandang yang berbeda. Sel yang mengalami apotosis akan mengalami fluorosensi warna hijau. Pemeriksaan dilakukan di bawah mikroskop fluorosen (Zeiss $®$ ) di LPPT UGM. Setelah itu dilakukan perhitungan indeks apoptosis.

\section{Analisis data}

Data pengamatan nilai apoptosis antar kelompok dianalisis menggunakan ANOVA (SPSS versi 16). Metode statistik yang digunakan adalah statistik parametrik dengan uji Kolmogorov Smirnov untuk uji normalitas (bila nilai signifikansi lebih dari 0,05 maka data terdistribusi normal), lalu dilanjutkan dengan uji homogenitas varian menggunakanan homogeinity of varians test (bila nilai signifikansi lebih dari 0,05 maka varian dari dua data atau lebih populasi data adalah sama), setelah itu dilakukan uji one way-ANOVA dan uji lanjut post-hoc test Tukey HSD dengan taraf kepercayaan $95 \%$.

\section{HASIL PENELITIAN}

\section{Induksi Kanker}

Injeksi 2\% DMBA dengan dosis $0,1 \mathrm{ml} / \mathrm{kg}$ BB pada lateral lidah tikus galur Spague dawley mengakibatkan timbulnya ulkus yang berwarna kemerahan disertai indurasi pada pemeriksaan klinis. Pada pengecatan HE, gambaran histologis lidah tikus menunjukkan adanya displasia epitel yang ditandai dengan pemanjangan epitel dan inti sel yang hiperkromatis (Gambar 1B). 


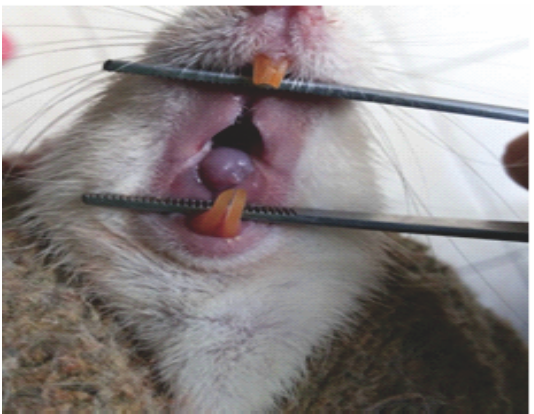

(A)

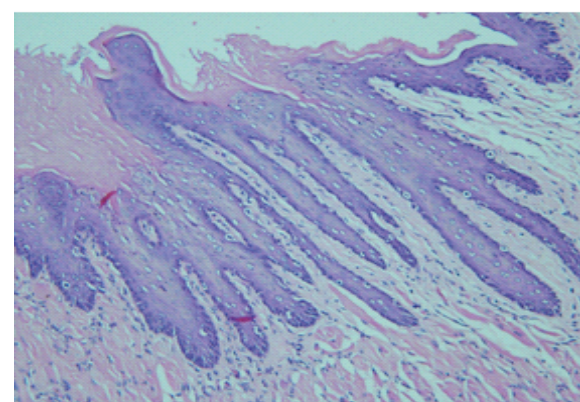

(B)

Gambar 1. Gambaran premalignansi lidah tikus jika dilihat (A) secara klinis, (B) dengan pengecatan $\mathrm{HE}$, diamati menggunakan mikroskop cahaya perbesaran 200x. Pada panah yang ditunjuk (Gambar A) menunjukkan adanya kondisi premalignasi dengan ciri indurasi pada pinggiran ulkus. Pada panah yang ditunjuk (Gambar B) menunjukkan retepeg irregular panjangnya, dan sel mengalami dysplasia.

Hasil pengecatan TUNEL menunjukkan bahwa apoptosis kelompok pelakuan EEC dengan dosis $1500 \mathrm{mg} / \mathrm{kg}$ BB memiliki jumlah apoptosis paling banyak jika dibandingkan dengan kelompok perlakuan EEC $750 \mathrm{mg} / \mathrm{kg}$ BB dan kelompok kontrol. sebesar $10,81 \%$, kemudian kelompok perlakuan ekstrak $750 \mathrm{mg} / \mathrm{kg}$ BB yaitu sebesar $9,41 \%$, dan yang terendah adalah indeks apoptosis pada kelompok kontrol, yaitu sebesar 3,94\%. (Gambar 3)

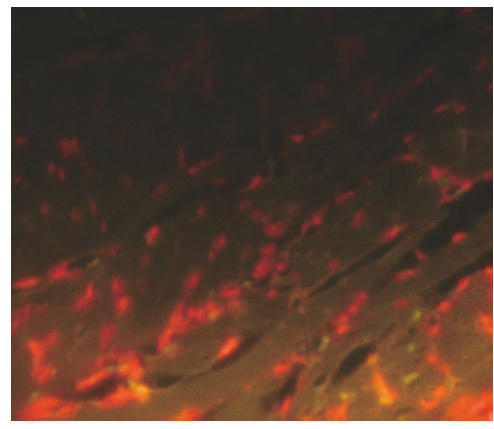

(A)

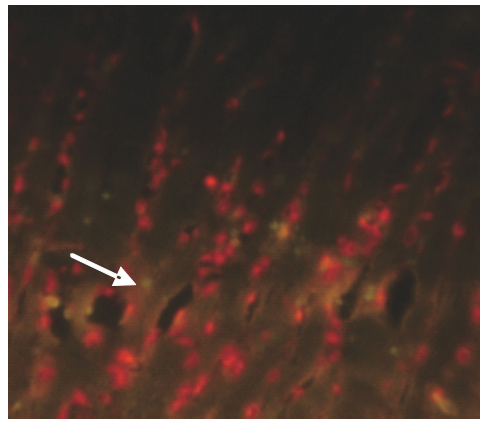

(B)

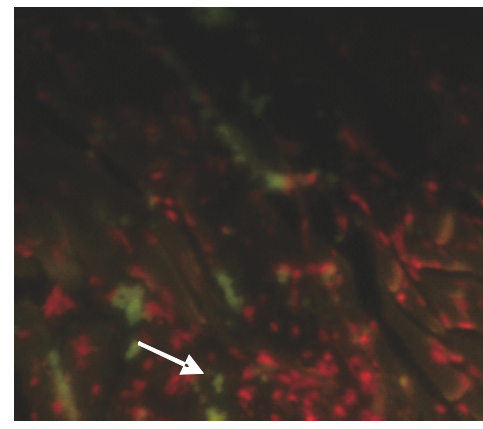

(C)

Gambar 2. Gambaran jaringan lidah tikus yang mengalami apoptosis sel dilihat dengan mikroskop fluorosensi perbesaran 400x. Kontrol DMBA (A); Perlakuan DMBA+ EEC 750 mg/kg BB (B); Perlakuan DMBA+ EEC 1500 mg/ kg BB (C). Tanda panah putih menunjukkan fluoresensi hijau yang mengindikasikan adanya apoptosis. Fluoresensi hijau ditemukan paling banyak pada perlakuan DMBA+EEC $1500 \mathrm{mg} / \mathrm{kg}$ BB. Gambar A menunjukkan tidak terjadi apoptosis.

\section{Indeks Apoptosis}

Indeks apoptosis dihitung menggunakan rumus:

$$
I A=(\text { sel apoptosis/total sel) } \times 100 \%
$$

Hasil perhitungan indeks apoptosis menunjukkan bahwa indeks apoptosis tertinggi adalah pada kelompok perlakuan ekstrak 1500 mg/kg BB yaitu

\section{Analisis Statistik}

Tabel 1. Rangkuman hasil uji Tukey HSD

\begin{tabular}{ccc}
\hline Signifikansi Tukey & $\begin{array}{c}\text { DMBA+EEC } \\
750 \mathrm{mg} / \mathrm{kgBB}\end{array}$ & $\begin{array}{c}\text { DMBA+EEC } \\
1500 \mathrm{mg} / \mathrm{kgBB}\end{array}$ \\
\hline DMBA & $0,000^{*}$ & $0,000^{*}$ \\
DMBA+EEC 750mg/kgBB & - & $0,001^{*}$ \\
\hline
\end{tabular}

*berbeda signifikan dengan $p<0,05$ 


\section{Indeks Apoptosis (IA)}

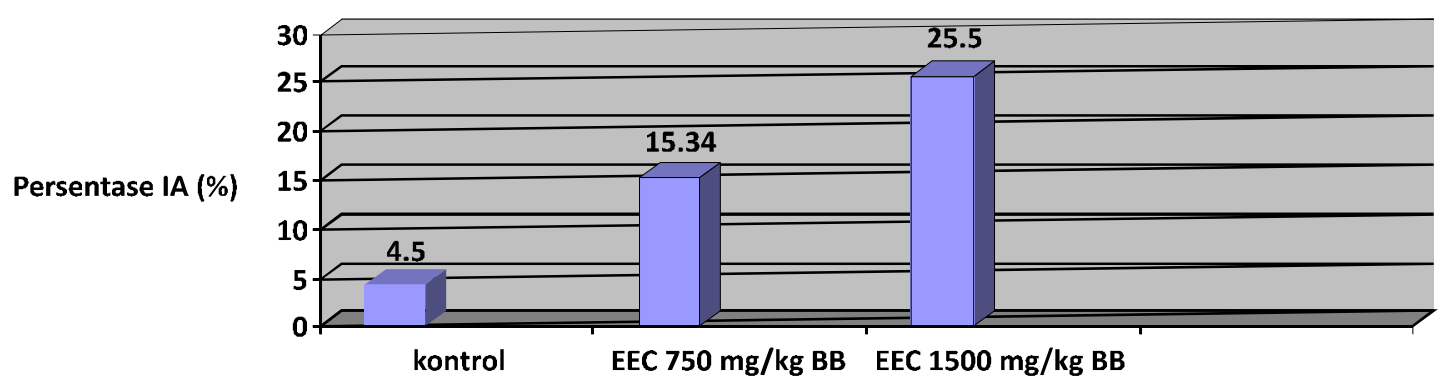

Gambar 3. Grafik indeks apoptosis. Persentase Indeks apoptosis kelompok perlakuan ekstrak $1500 \mathrm{mg} / \mathrm{kg} \mathrm{BB}$ adalah sebesar 10,81\%, indeks apoptosis kelompok perlakuan ekstrak $750 \mathrm{mg} / \mathrm{kg}$ BB adalah sebesar $9,41 \%$, dan yang indeks apoptosis pada kelompok kontrol adalah sebesar 3,94\%

Secara statistik, hasil kuantifikasi indeks apoptosis masing-masing kelompok perlakuan dalam penelitian ini menunjukkan hasil yang terdistribusi normal dan homogen. Hasil uji One Way ANOVA menunjukkan nilai $0,000 \quad(p<0,05)$ yang artinya terdapat perbedaan yang signifikan antar kelompok. Hal ini mengindikasikan bahwa EEC mampu meningkatkan indeks apoptosis kanker lidah tikus yang diinduksi DMBA. Setelah dilakukan uji One Way ANOVA dilanjutkan uji posthoc Tukey HSD. Nilai signifikansi uji analisis statistik menggunakan Tukey test dapat dilihat pada Tabel 1.

Pada Tabel 1 terlihat kelompok kontrol DMBA berbeda secara signifikan dengan kelompok perlakuan EEC $750 \mathrm{mg} / \mathrm{kg}$ BB dan EEC $1500 \mathrm{mg} / \mathrm{kg}$ $B B$ yang artinya EEC mampu meningkatkan indeks apoptosis kanker lidah tikus yang diinduksi DMBA. Perlakuan EEC $750 \mathrm{mg} / \mathrm{kg}$ BB berbeda secara signifikan dengan perlakuan ekstrak $1500 \mathrm{mg} / \mathrm{kg}$ BB yang artinya EEC $1500 \mathrm{mg} / \mathrm{kg}$ BB lebih efektif meningkatkan indeks apoptosis dibandingkan EEC $750 \mathrm{mg} / \mathrm{kg}$ BB.

\section{PEMBAHASAN}

Pada penelitian ini teknik penyuntikan secara intrasubmukosa di lateral lidah dengan 7,12-Dimetilbenz[a]antrasena (DMBA) pada lidah tikus Sprague dawley pertama kali dilakukan, sebelumnya teknik ini dilakukan pada hewan uji lidah hamster. Pemberian (DMBA) pada tikus selama 5 minggu menyebabkan tikus mengalami fase prekanker. Hal tersebut sesuai dengan penelitian
Chino dkk. ${ }^{14}$ bahwa DMBA 0,25\% yang dipaparkan pada lidah hamster secara intrasubmukosa mampu menginduksi terjadinya kanker lidah. Metabolit DMBA bersifat elektrofilik, sangat reaktif, dan mampu bereaksi dengan makromolekul di dalam tubuh (seperti DNA, RNA, dan protein) yang bersifat nukleofilik dengan membentuk ikatan kovalen. Ikatan kovalen adalah awal dari stress sel yang akan menyebabkan kerusakan kromosom, kesalahan replikasi DNA, dan pembelahan yang tidak wajar yang mengakibatkan perubahan sifat sel-sel normal menjadi sel kanker yang tidak terkendali. ${ }^{9}$

Hasil penelitian ini menunjukkan adanya peningkatan apoptosis pada sel prekanker lidah. Hal ini disebabkan zat aktif dalam ciplukan berupa fisalin dapat meningkatkan terjadinya apoptosis pada sel. ${ }^{15}$ Ekstrak etanolik herba ciplukan mampu menginduksiapoptosis melalui penurunan membran potensial mitokondria dan perubahan permeabilitas membran mitokondria sehingga terjadi kerusakan mitokondria yang akan memicu penurunan protein $\mathrm{Bcl}$ dan meningkatkan gen p53 yang selanjutnya akan mengaktifkan protein proapoptosis sehingga terjadi apoptosis. Hasil penelitian ini sesuai dengan hasil penelitian yang dilakukan Monikawati, bahwa fisalin F mampu memicu terjadinya apoptosis pada sel T-47D kanker payudara melalui mekanisme pengaktifan kaspase-3. ${ }^{16} \mathrm{Hal}$ ini sesuai dengan penelitian Wu dkk., bahwa pemberian EEC mampu menurunkan ekspresi protein $\mathrm{Bcl}-2 .{ }^{17}$ Hasil tersebut mendukung penelitian in vitro yang dilakukan oleh Lee dkk., bahwa EEC mampu meginduksi apoptosis pada sel HSC-3 (human oral cancer cells) melalui 
penurunan membran potensial mintokondria, perubahan permeabilitas membran mitokondria, serta penurunan protein ekspresi protein Bcl2 sehingga memicu terjadinya apoptosis. ${ }^{17}$ Peningkatan apoptosis ini dapat menjadi salah satu target dalam pengobatan kanker lidah, sehingga perlu penelitian biomolekuler lebih lanjut untuk mengetahui keterlibatan molekuler terkait dengan mekanisme EEC menginduksi apoptosis pada sel kanker lidah.

\section{KESIMPULAN}

Dari penelitian ini dapat ditarik kesimpulan bahwa pemberian EEC 750 dan $1500 \mathrm{mg} / \mathrm{kg}$ BB mampu meningkatkan apoptosis pada kanker lidah tikus yang diinduksi DMBA sehingga EEC ini dapat dijadikan salah satu alternatif dalam pengobatan kanker lidah. Perlu dilakukan penelitian mengenai ekspresi gen p53 setelah pemberian EEC pada tikus Sprague Dawley.

\section{DAFTAR PUSTAKA}

1. Schwartz. Principles of Surgery $7^{\text {th }}$. Jakarta: Penerbit Buku Kedokteran EGC. 2000.

2. Harun A, Satari, Oewen, Supriatno. Aktivitas antitumor agen celecoxib terhadap invasi sel kanker lidah SP-C1 (kajian in vitro). Padjajaran J. Dent. 2011; 23(1): 1 - 5.

3. Kementerian Kesehatan Republik Indonesia. Riset Kesehatan Dasar Riskesdas. Oleh Badan Penelitian dan Pengembangan Kesehatan. 2013. http://www.depkes.go.id/ resources/download/general/Hasil\%20 Riskesdas\%202013.

4. Sirait. Faktor resika tumor/kanker rongga mulut dan tenggorokan di Indonesia (Analisis Riskesdas 2007). Media Litbangkes. 2007; 2(3): $122-129$.

5. Wong, Rebecca SY. Apoptosis in cancer: from pathogenesis to treatment. J.Exp.Clin. Cancer Res. 2011; 1(30): 87.
6. Alberts B, Alexander J, Julian L. Molecular biology of the cell. $4^{\text {th }}$ ed. New York: Garland Science. 2002.

7. Kumar V, Abul KA, Nelson F. Pathologic basis of disease. $7^{\text {th }}$ ed. Pennsylvania: Elsevier Saunders. 2007.

8. Yu H, Yan J, Jiao Y, Fu PP. Photochemical reaction of 7,12-dimethylbenz[a]anthracene (DMBA) and formation of DNA covalent adducts, Int. J. Environ Res. Public Health. 2005; 1(2): 114 - 122.

9. King, Roger JB, Mike W Robins. Cancer Biology. $3^{\text {rd }}$ Edition. London: Pearson Eduation Limited. 2006.

10. Cardenas V, Mace D, Richardson, Wilson DF, Shan S, Dewhisrt MW. The pervasive presence of fluctuating oxygenation in tumors. Cancer Res. 2008; 68: 5812.

11. Andita PD, Rosana A, Perdana A, Ameilinda $M$, Ilham AF, Adam H, Edy M. Aktivitas sitotoksisitas ekstrak etanolik herba ciplukan (Physalis angulata $L$ ) terhadap kanker rahim HeLa melalui modulasi ekspresi protein p53. Jurnal Statistika. 2010; 2: 2.

12. Maya F, Inna A, Dita B, Adam H, Muthi I, Edy M. Ekstrak etanolik herba ciplukan (Physalis angulata L.) berefek sitotoksik dan menginduksi apoptosis pada sel kanker payudara MCF- 7. Jurnal Bionatura. 2011; 13(2): $101-107$.

13. Magalhaes HI, Veras ML, Torres MR, Alves AP, Pessoa OD, Silveira, Costa LLV, de Moraes MO, Pessoa C. In-vitro and in-vivo antitumor activity of physalins $B$ and $D$ from physalis angulata. J. Pharm Pharmacol. 2006; 58(7): $235-241$.

14. Takehiro C, Yuzo S, Toshitaka K, Akio U. Experimental production of lingual tumor by Jet Injection of 9,10-dimethyl 1,2-benzanthracene. Matsumoto Shigaku. 1983; 9: $174-182$.

15. Wu M, Ding HF, Fisher DE. Apoptosis: molecular mechanism. Nature. 2001; 1 - 8. 
16. Ooi, Muhammad, Sulaiman. Physalin F from physalis minima L.Triggers apoptosis-based cytotoxic mechanism in T-47D cells through the activation caspase-3- and c-myc-dependent pathways. J. Ethnopharmacol. 2013; 150(1): $382-388$.
17. Lee HZ, Liu WZ, Hsieh WT, Tang FY, Chung JG, Leung HW. Oxidative stress involvement in physalis angulata-induce apoptosis in human oral cancer cells. Food Chem. Toxicol. 2009; 47: 561 - 570 . 